\title{
Studies on Somatic Embryognesis in Chrysanthemum cv. Marigold Using Root and Leaf as Explants
}

\author{
Subhasini Ghosh ${ }^{1}$, Mahantesha B.N. Naika ${ }^{1 *}$, Sandhyarani Nishani ${ }^{1}$, \\ Mukund Shiragur ${ }^{2}$ and Amruta Bhat ${ }^{3}$
}

${ }^{1}$ Department of Biotechnology and crop improvement, K.R.C. College of Horticulture, Arabhavi-591218, University of Horticultural Sciences, Bagalkot, Karnataka, India

${ }^{2}$ Department of Floriculture and Landscape Architecture, K.R.C. College of Horticulture, Arabhavi-591218, University of Horticultural Sciences, Bagalkot, Karnataka, India

${ }^{3}$ Department of Horticulture Plant Pathology, K.R.C. College of Horticulture, Arabhavi591218, University of Horticultural Sciences, Bagalkot, Karnataka, India

*Corresponding author

\section{A B S T R A C T}

\section{Keywords}

Chrysanthemum, Tissue culture, Root, Leaf, Somatic embryogenesis, Plant regeneration

Article Info

Accepted:

22 July 2018

Available Online:

10 August 2018
Chrysanthemum is a second most important flower crop globally. Marigold is a introduced cultivar gaining popularity among farmers and consumers of southern part of India due to its colour and high shelf life. Due to its commercial importance as quality planting material and cut flowers it is difficult to mitigate the gradually increasing demand by only vegetative means of propagation which is time consuming with low multiplication rate. Plant tissue culture is a better alternative tool to overcome conventional limitations. We have used leaf and root explants and cultured in MS medium containing different concentration of BAP, 2,4-D, NAA and different growth components such as L-proline and caesin hydrolysate. Root explants produced poor quality callus without any plant regeneration, whereas leaf explants showed somatic embryogenesis in turn plant regeneration in various degree in different media. From this study it is understood that the leaf explants can be successfully utilized for the plant regeneration through somatic embryogeneis in chrysanthemum.

\section{Introduction}

Chrysanthemum (Dendranthema grandiflora Tzvelev), is one of the most important flower crops popularly known as "queen of the east", belongs to the family Asteraceae, genus Chrysanthemum and its relatives grown commercially in India and different parts of the world for cut and loose flower, and also used as pot and garden flower (Silva, 2003;
Xia et al., 2006; Koley and Sarkar, 2013). In India, chrysanthemum commercially grown in Karnataka, Tamil Nadu, Andhra Pradesh, Maharastra and West Bengal, is mainly grown for making garlands, bracelets, bouquets, venis and flower decoration during social and religious functions (Bohra and Kumar, 2014; Patil et al., 2017). In south India, yellow coloured flowers are preferred and farmers grow chrysanthemum flower in their fields for 
supply to the market as loose flowers for various usage, in north India, flowers are grown abundance of various colours like red, yellow, purple and white (Gunabhagya, 2014). In 2016-17 the total area under cut flower production was estimated as 20,550 hectares with a production of 188.81 metric tones (MT) and cut flowers in a quantity of 15.38 lakhs, whereas in 2014-15 in Karnataka total area under Chrysanthemum production is 5,100 hectares with a production of 106.76 MT and 6.03 lakhs of cut flowers (Anonymous, 2018). The cultivar Marigold is introduced and very popular in Southern part of India and is being cultivated by the local farmers as well as in high demand to the consumers due to its bright yellow colour, orientation of ray florets and specially high shelf life alongside high rate of production.

Somatic embryogenesis is a process where the vegetative cells organize themselves into compact cell masses and pass through the characteristic embryological stages similar to the stages in development of zygotic embryos viz. globular, heart and torpedo stages and develop into bipolar embryos. The induction of somatic embryogenesis in chrysanthemums in cultures in vitro is affected e.g. by many factors like growth regulators (May and Trigiano, 1991; Tanaka et al., 2000; Mandal and Datta, 2005) and the genotype (Pavingerová et al., 1994). The efficiency of regeneration is also enhanced by the division of the explant, which is connected with an intensified inflow, into the areas of the cutting places, of endogenous growth regulators as well as with an intensive uptake of exogenous growth regulators and the proliferation of the callus tissue (Gahan and George, 2008).

Numerous amounts of plantlets can be produced from a minimum amount of explants by somatic embryogenesis which involves development of plants from somatic or vegetative tissues that give no regeneration under natural breeding condition (Hasbullah et al., 2015). In this present study different plant parts have been used for somatic embryogenesis under different growth media to find out the best suitable combination for better growth and higher production.

\section{Materials and Methods}

The study was carried out in the Department of Biotechnology and Crop Improvement, Kittur Rani Channamma College of Horticulture (K.R.C.C.H.), Arabhavi, UHS, Bagalkot, Karnataka. Chrysanthemum cv. Marigold has been used for the experiment.

Leaf and root used as explants for direct somatic embryogenesis. Four different media along with control were used for this experiment. Following is the details of media.

$\mathrm{M}_{0}$ : Control

$\mathrm{M}_{1}$ : 2,4-D (1.5mg/l); Casein hydrolysate (200 $\mathrm{mg} / \mathrm{l})$; L-Proline $(290 \mathrm{mg} / \mathrm{l})$

$\mathrm{M}_{2}$ : NAA (1 mg/l); BAP (0.1mg/l); Casein hydrolysate (200 mg/l); L-Proline $(290 \mathrm{mg} / \mathrm{l})$

$\mathrm{M}_{3}$ : 2,4-D (1mg/l); BAP (3 mg/l); Casein hydrolysate $(150 \mathrm{mg} / \mathrm{l})$; L-Proline $(50 \mathrm{mg} / \mathrm{l})$

M4: NAA (1.5 mg/l); BAP (3 mg/l); Casein hydrolysate (150 mg/l); L-Proline $(50 \mathrm{mg} / \mathrm{l})$

All the observations were taken after 45 days of culture and quality of callus produced from different explants under different media condition was also recorded (0: No callus; +: Poor growth of callus; ++: Moderate growth of callus; +++: Vigorous growth of callus) as reported by Mahindrakar (2015).

The experiment was laid out in CRD (Completely randomized design) considering with two replications and five plants in each 
replication. Observed data were statistically analyzed using analysis of variance technique (ANOVA).

\section{Results and Discussion}

Aiming to the standardization of media and best explants for efficient somatic embryogenesis, in this experiment two different explants were inoculated in different media and data of different parameters were taken after 45 days of inoculation.

No callus (0) was produced in control (without any growth regulators) media by any of the explants. Among the two explants, roots showed poor watery callus growth $(+)$ only in $\mathrm{M}_{2}$ (NAA (1 mg/l); BAP (0.1mg/l); Casein hydrolysate $(200 \mathrm{mg} / \mathrm{l})$; L-Proline $(290 \mathrm{mg} / \mathrm{l})$ ) media whereas in other media it produced no callus (0). Leaf explants developed vigorous callus growth in $\mathrm{M}_{1}(2,4-\mathrm{D}(1.5 \mathrm{mg} / \mathrm{l})$; Casein hydrolysate $(200 \mathrm{mg} / \mathrm{l})$; L-Proline $(290 \mathrm{mg} / \mathrm{l})$ ) and $\mathrm{M}_{4}$ (NAA (1.5 mg/l); BAP (3 mg/l); Casein hydrolysate (150 mg/l); L-Proline(50 $\mathrm{mg} / \mathrm{l})$ ) media whereas in $\mathrm{M}_{3}$ (2,4-D (1mg/l); BAP (3 mg/l); Casein hydrolysate $(150 \mathrm{mg} / \mathrm{l})$; L-Proline $(50 \mathrm{mg} / \mathrm{l}))$ and $\mathrm{M}_{2}$ media it resulted in moderate callus growth (++) (Fig. 1).

Leaf explants produced no callus in control medium. Earliest initiation of callus was observed in M1 media whereas the highest time was taken in M3 media. Callus was only produced from root in M3 medium. Leaf and explants produced no shoot in $\mathrm{M}_{3}$ media. Earliest plant regeneration was observed in M1 media followed by M2 media, and highest time was needed for M4 media. The maximum number of shoots was produced in $\mathrm{M}_{4}$ media, whereas the number of shoots produced in M1 and M3 media was on par with each other. Highest shoot length was observed in plantlets regenerated in M1 medium and the shortest was observed in M4 medium. Roots were only regenerated in M1 and M2 media.
Somatic embryogenesis plays a significant role in mass propagation in vitro, germplasm conservation, and genetic improvement of woody. Efficiency of different explants and growth regulator composition was checked on MS media for direct somatic embryogenesis of Chrysanthemum cv. Marigold. Direct embryogenesis is more suitable for plant regeneration because it diminishes the possibility of somaclonal variation, an undesirable phenomena in the regeneration of specific genotypes (Keresa et al., 2012).

In the present study among the different explants leaf explants produced the best quality callus. The higher number of shoots was observed in MS media containing NAA (1.5 mg/l); BAP (3 mg/l); Casein hydrolysate (150 $\mathrm{mg} / \mathrm{l})$; L-Proline $(50 \mathrm{mg} / \mathrm{l})$ and the highest number of roots were produced in MS media containing NAA (1 mg/l); BAP $(0.1 \mathrm{mg} / \mathrm{l})$; Casein hydrolysate $(200 \mathrm{mg} / \mathrm{l})$; LProline $(290 \mathrm{mg} / \mathrm{l})$.

In the present study it was noticed that intermediate concentration of 2,4-D with high concentration of BAP resulted in moderate to high growth of callus. Shinoyama et al., (2004) reported no callus formation in control media (without any growth regulators) from leaf explants of Chrysanthemum cv. Kitamura, whereas the moderate growth was observed in media containing $1.0 \mathrm{mg} / 1$ 2,4-D and $2.0 \mathrm{mg} / \mathrm{l}$ BAP and vigorous growth was observed in media supplemented with $1.0 \quad \mathrm{mg} / \mathrm{l}$ concentration of both 2,4-D and BAP which supported the current observation. Keresa et al., (2012) reported highest number of embryogenic callus formation in Chrysanthemum from leaf petioles in MS media containing $1 \mathrm{mg} / \mathrm{L} \mathrm{2,4-D,} 0.1 \mathrm{mg} / \mathrm{L} \mathrm{BA}$, $200 \mathrm{mg} / \mathrm{L} \mathrm{CH}, 290 \mathrm{mg} / \mathrm{L}$ L-proline, $30 \mathrm{~g} / \mathrm{L}$ sucrose (100) followed by leaf petioles in media supplemented with $1 \mathrm{mg} / \mathrm{L}$ NAA, 0.1 mg/L BA, 200 mg/L CH, 290 mg/L L-proline, $30 \mathrm{~g} / \mathrm{L}$ sucrose (98.5) whereas the lower 
number of embryogenic callus formation was noticed from intermodal segments in the

above mentioned media (32.0 and 38.3 respectively) (Table 1 and 2).

Table.1 Effect of different Media treatments on callus induction of Chrysanthemum cv.

Marigold from different explants at 40 days

\begin{tabular}{|c|c|c|c|}
\hline SI. No. & Media & Leaf explants & Root \\
\hline 1 & $\mathrm{M}_{0}$ & 0 & 0 \\
\hline 2 & $\mathrm{M}_{1}$ & +++ & 0 \\
\hline 3 & $\mathrm{M}_{2}$ & ++ & + \\
\hline 4 & $\mathrm{M}_{3}$ & ++ & 0 \\
\hline 5 & $\mathrm{M}_{4}$ & +++ & 0 \\
\hline
\end{tabular}

Table.2 Somatic embryogenesis of Chrysanthemum cv. Marigold from leaf explants using different growth component in MS media

\begin{tabular}{|c|c|c|c|c|c|c|}
\hline SI No. & Treatment & $\begin{array}{c}\text { Days to } \\
\text { initiate } \\
\text { callus }\end{array}$ & $\begin{array}{c}\text { Days to } \\
\text { initiate } \\
\text { Plants }\end{array}$ & $\begin{array}{c}\text { Shoot } \\
\text { length(cm) }\end{array}$ & $\begin{array}{c}\text { No. of } \\
\text { shoots per } \\
\text { clump }\end{array}$ & $\begin{array}{c}\text { No. of } \\
\text { roots per } \\
\text { clump }\end{array}$ \\
\hline 1 & $\mathrm{M}_{0}$ & $0^{\mathrm{e}}$ & $0^{\mathrm{d}}$ & $0^{\mathrm{d}}$ & $0^{\mathrm{c}}$ & $0^{\mathrm{b}}$ \\
\hline 2 & $\mathrm{M}_{1}$ & $16.6^{\mathrm{d}}$ & $21.9^{\mathrm{c}}$ & $3.46^{\mathrm{a}}$ & $1.3^{\mathrm{b}}$ & $3.3^{\mathrm{a}}$ \\
\hline 3 & $\mathrm{M}_{2}$ & $18.4^{\mathrm{c}}$ & $24.9^{\mathrm{b}}$ & $2.7^{\mathrm{b}}$ & $1.6^{\mathrm{b}}$ & $2.9^{\mathrm{a}}$ \\
\hline $\mathbf{4}$ & $\mathrm{M}_{3}$ & $24.3^{\mathrm{a}}$ & $0^{\mathrm{d}}$ & $0^{\mathrm{d}}$ & $0^{\mathrm{c}}$ & $0^{\mathrm{b}}$ \\
\hline $\mathbf{5}$ & $\mathrm{M}_{4}$ & $22.8^{\mathrm{b}}$ & $30.5^{\mathrm{a}}$ & $1.39^{\mathrm{c}}$ & $4.4^{\mathrm{a}}$ & $0^{\mathrm{b}}$ \\
\hline $\mathrm{CD}$ & & $\mathbf{1 . 3 8}$ & $\mathbf{1 . 9 7}$ & $\mathbf{0 . 4}$ & $\mathbf{0 . 3 6}$ & $\mathbf{1 . 3 9}$ \\
\hline @5\% & & & & & & \\
\hline $\mathrm{CD}$ & & $\mathbf{2 . 1 7}$ & $\mathbf{3 . 0 9}$ & $\mathbf{0 . 6 3}$ & $\mathbf{0 . 5 4}$ & $\mathbf{2 . 1 9}$ \\
\hline @ 1\% & & & & & & \\
\hline SE.m \pm & & $\mathbf{3 . 2 9}$ & $\mathbf{4 . 9 6}$ & $\mathbf{1 0 . 4 3}$ & $\mathbf{9 . 6 8}$ & $\mathbf{4 3 . 8 7}$ \\
\hline CV(\%) & & 0.38 & 0.54 & 0.11 & 0.1 & 0.38 \\
\hline
\end{tabular}

Fig.1 Effect of different explants on quality of callus production

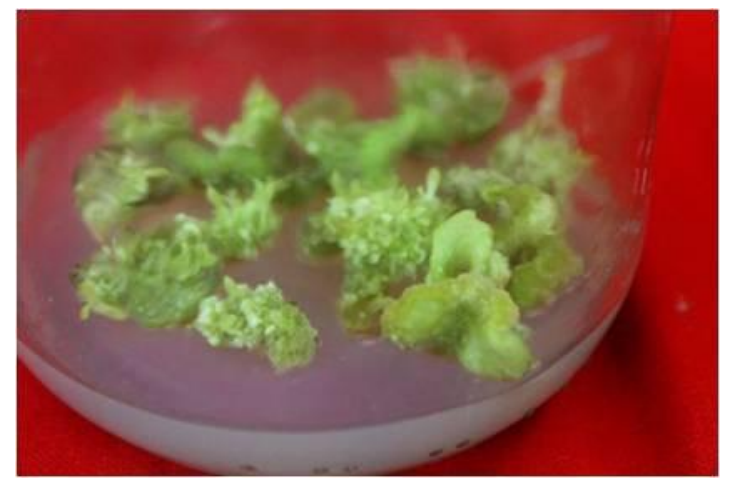

A. Vigorous green callus growth and shoot formation from leaf explants 


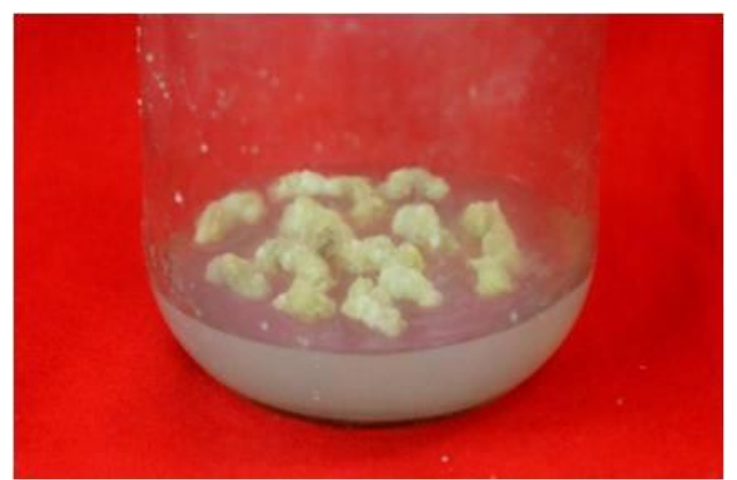

\section{B. Poor quality cream coloured callus growth from root explants}

Mahindarkar (2015) reported the earliest callus formation from Gerbera seeds in MS media containing $1 \mathrm{mg} / \mathrm{l}$ of both BAP and 2,4$\mathrm{D}$ (25.87) days where as higher concentration of cytokinin (5 mg/l BAP or Kinetin) along with $1 \mathrm{mg} / 1$ 2,4-D took the maximum time to initiate callus (33 days).

Barakat et al., (2010) found highest number of shoot formation in MS media containing $0.5 \mathrm{mg} / \mathrm{l} \mathrm{BAP}$ and $0.2 \mathrm{mg} / \mathrm{l} \mathrm{NAA} \mathrm{(1.7)} \mathrm{from}$ callus clump produced from ray florets of Chrysanthemum, while no shoot formation was observed in media fortified with no BAP, $0.2 \mathrm{mg} / \mathrm{l} \mathrm{NAA}$ and $2.0 \mathrm{mg} / \mathrm{l}$ Kinetin.

Tymoszuk et al., (2014) showed highest number of root formation per inoculated ray florets of Chrysanthemum in media containing $18.08 \mu \mathrm{M}$ of $2,4-\mathrm{D}$ and $4.65 \mu \mathrm{M}$ of Kinetin with no BAP (1.40) whereas the no root formation was noticed in media containing $18.08 \mu \mathrm{M}$ of $2,4-\mathrm{D}$ and $8.8 \mu \mathrm{M}$ of BAP with no kinetin.

Spray cultivars of Chrysanthemum has been subjected to somatic embryogenesis, however, the magnitude of somatic embryogenesis and plant regeneration have been reported to be lower (Tanaka et al., 2000; May and Trigiano, 1991; Mandal and Datta, 2005). Naing et al., (2014) reported $70 \%$ of somatic embryo germination in in Chrysanthemum cv. 'Baeksun'. Jaramillo et al., (2008) somatic embryogenesis in variety
White Albatross and Yellow Albatross after a duration of 14 and 21 days respectively upon exposing the leaf discs in $2.26 \mu \mathrm{M}$ 2,4-D supplemented MS media.

The reason behind high numbers of somatic embryos per explant, and especially the conversion rate to plantlets could be from using the organic supplements proline and casein hydrolysate $(\mathrm{CH})$ in the media. Proline has been proven to have a positive influence on embryogenic callus formation in Iris (Jéhan et al., 1994; Kereša et al., 2009), whereas $\mathrm{CH}$ has induced somatic embryos from root explants in carrots (Smith et al., 1997). Purohit and Kothari (2007) reported that subculturing bishop's weed somatic embryos in MS medium supplemented with $100 \mathrm{mg} / \mathrm{L}$ of $\mathrm{CH}$ significantly promoted the maturation of heart and torpedo stage to cotyledonary stage somatic embryos.

The best quality callus was produced from leaf explants in MS media containing 2,4 1 $\mathrm{mg} / \mathrm{l}$, Casin hydrolyzate $200 \mathrm{mg} / \mathrm{l}$ and LProleine 290 mg/l. Whereas roots were incapable of producing callus in any of the media. MS media containing NAA $1.5 \mathrm{mg} / \mathrm{l}$, BAP $3 \mathrm{mg} / \mathrm{l}$, casein hydrolyzate $150 \mathrm{mg} / \mathrm{l}$ and L-Prolein $50 \mathrm{mg} / \mathrm{l}$ has produced the higest number of shoots per clump. Somatic embryogenesis in Chrysanthemum is having a huge potential for higher multiplication as well as to create novel variations and should be more exploited. 


\section{Acknowledgement}

SG thank ICAR, New Dehli for National talent scholarship during M.Sc. (Hort.) in BCI, MBNN, SN, MS and AB thank UHS, Bagalkot for infrastructure facilities.

\section{References}

Anonymous, 2018, Statistical Data on Horticultural Crops in Karnataka and India. www.indiastat.com

Barakat, M.N., Rania S., Fattah, A., Badr, M. and Torky, M.G.E., 2010. In vitro culture and plant regeneration derived from ray florets of Chrysanthemum morifolium. Afr. J. of Biotechnol. 9(8): 1151-1158.

Bohra, M. and Kumar, A., 2014. Studies on effect of organic manure and bioinoculants on vegetative and floral attributes of chrysanthemum cv. little darling. The Bioscan, 9(3): 1007-1010.

Gahan, P.B. and George, E.F., 2008. Adventitious regeneration. In: Plant propagation by tissue culture. Springer. Dordrecht. 1(3): 358-389.

Gunabhagya, 2014. Production and marketing of chrysanthemum flower in Tumkur district - an economic analysis. Dharwad, India. M.Sc (Agri.) Thesis, Univ. Agri. Sci., Dharwad, India.

Jaramillo1, E.H., Forero1, A., Cancino, G., Moreno, A.M., Monsalve, L.E. and Acero, W., 2008. In vitro regeneration of three Chrysanthemum (Dendrathema grandiflora) varieties "via" organogenesis and somatic embryogenesis regeneración in vitrob de tres variedades de crisantemo (Dendrathema grandiflora) a través de organogénesis y embriogénesis somatic. Universitas Scientiarum. 13 (2): 118127.

Jéhan, H., Courtois, D., Ehret, C., Lerch, K. and Pétiard, V., 1994. Plant regeneration of Iris pallida Lam. and Iris germanica L. via somatic embryogenesis from leaves, apices and young flowers. Plant Cell Rep. 13(12): 671-675.

Keresa, S., Mihovilovic1, A., Baric, M., Vesna, Z. V. and Skelin, M., 2012. The micropropagation of Chrysanthemums via axillary shoot proliferation and highly efficient plant regeneration by somatic embryogenesis. Afr. J. of Biotechnol. 11(22): 6027-6033.

Kereša, S., Mihovilović, A., Ćurković-Perica, M., Mitić, B., Barić, M., Vršek, I. and Marchetti, S., 2009. In vitro regeneration of Croatian endemic species Iris adriatica Trinajstić ex Mitić. Acta Biol. Cracov. Bot. 51(2): 712.

Koley, S. and Sarkar, M.M., 2013. Measurement of PAR and its impact on chrysanthemum (Chrysanthemum morifolium Ramaat). The Bioscan. 8(1): 169-172.

Mahindrakar, A. 2015. Development and evaluation of Gerbera (Gerbera jamesonii Bolus ex. Hooker F.) hybrids for novel characters, Bagalkot, India. M.Sc. (Hort.) Thesis, Univ. Hort. Sci., Bagalkot, India.

Mandal, A.K.A. and Datta, S.K., 2005. Direct somatic embryogenesis and plant regeneration from ray florets of chrysanthemum. Biol. Plant. 49(1): 2933.

May, R. A., and Trigiano, R. N., 1991. Somatic embryogenesis and plant regeneration from leaves of Dendranthema grandiflora. J. Amer. Soc. Hort. Sci. 116(2): 366-371.

Naing, A., H., Min, J.S., Park, K., Chung, M.Y., Lim, S., H., Lim, K.B. and Kim, C.K., 2014. Primary and secondary somatic embryogenesis in chrysanthemum (Chrysanthemum morifolium) cv. 'baeksun' and 
assessment of ploidy stability of somatic embryogenesis process by flow cytometry. Acta Physiol Plant. 1(35): 2965-2974.

Patil, U.H., Karale, A.R., Katwate, S.M. and Patil, M.S., 2017. Mutation breeding in chrysanthemum (Dendranthema grandiflora T.). J. of Pharmacogn and Phytochem. 6(6): 230-232.

Pavingerona, D., Dostál, J., Bísková, R. and Benetka, V., 1994. Somatic embryogenesis and Agrobacteriummediated transformation of chrysanthemum. Plant Sci. 97: 95-101.

Purohit, S. and Kothari, S.L., 2007. Direct somatic embryogenesis from cotyledon and cotyledonary node explants in bishop's weed Trachyspermum ammi (L.) sprague. In vitro. Cell. Dev. Biol. Plant. 43(2): 154-158.

Shinoyama, H., Nomurai, Y., Tsuchiya,T., and Kazuma,T., 2004. A Simple and effilcient Method for somatic embryogenesis and plant regeneration from leaves of chrysanthemum [dendranthema $\mathrm{x}$ ifl jgrandl orum (ramat.) kitamura. Plant Biotechnology. 1, 25- 33 .
Silva, T.D., 2003. Chrysanthemum: advances in tissue culture, cryopreservation, postharvest technology, genetics and transgenic biotechnology. Biotechnol Adv. 21, 715-766.

Smith, R.A., Jacobs, D., Desai, D., Gruber, J., Kittipongpatana, N. and Godin, W., 1997, Optimization of culture medium extends response time of embryogenic carrot cells but does not restore initial high response of young cultures. Plant Cell Tissue Organ Cult. 49(1): 63-65.

Tanaka, K., Kanno, Y., Kudo, S. and Suzuki, M., 2000. Somatic embryogenesis and plant regeneration in chrysanthemum (Dendranthema grandiflorum Kitamura). Plant Cell Rep. 19: 946-953. Tymoszuk, A., Zalewska, M. and Rumieska, J.L., 2014. Regeneration of somatic embryos from in vitro isolated ligulate florets of chrysanthemum. Acta Sci. Pol. Hortorum Cultus. 13(4): 13-22.

Xia, Y., Lu, L.J. and Gerstein, M., 2006. Integrated prediction of the helical membrane protein interactome in yeast. J Mol Biol. 357(1): 339-49.

\section{How to cite this article:}

Subhasini Ghosh, Mahantesha B.N. Naika, Sandhyarani Nishani, Mukund Shiragur and Amruta Bhat. 2018. Studies on Somatic Embryognesis in Chrysanthemum cv. Marigold Using Root and Leaf as Explants. Int.J.Curr.Microbiol.App.Sci. 7(08): 3965-3971. doi: https://doi.org/10.20546/ijcmas.2018.708.409 